The Quaternary Sedimentology and Stratigraphy of Small, Ice-Proximal, Subaqueous Grounding-Line Moraines in the Central Niagara Peninsula, Southern Ontario La sédimentologie et la stratigraphie du Quaternaire des petites moraines de limite d'ancrage proximales et sub-aquatiques, au centre de la péninsule du Niagara, dans le sud de l'Ontario Quartär-Sedimentation kleiner, Eis-proximalersubaquatischer Verankerungsmoränen im Zentrum der Niagara-Halbinsel, Süd-Ontario.

John Menzies

Volume 55, numéro 1, 2001

URI : https://id.erudit.org/iderudit/005658ar

DOI : https://doi.org/10.7202/005658ar

\section{Aller au sommaire du numéro}

\section{Éditeur(s)}

Les Presses de l'Université de Montréal

\section{ISSN}

0705-7199 (imprimé)

1492-143X (numérique)

\section{Découvrir la revue}

\section{Citer cet article}

Menzies, J. (2001). The Quaternary Sedimentology and Stratigraphy of Small, Ice-Proximal, Subaqueous Grounding-Line Moraines in the Central Niagara Peninsula, Southern Ontario. Géographie physique et Quaternaire, 55(1), 75-86. https://doi.org/10.7202/005658ar

\section{Résumé de l'article}

Une série de petites crêtes morainiques situées au centre de la péninsule du Niagara a été étudiée afin de pré-ciser les effets du retrait de l'Inlandsis laurentidien dans cette région, en ce qui a trait à la sédimentologie, la stratigraphie et la géomorphologie du Quaternaire. Pendant le retrait même des glaces du bassin du lac Érié, la région a été inondée par une série de lacs glaciaires. La seule résultante morphologique de cette phase de retrait est l'édification de petites crêtes morainiques. La morphologie, la stratigraphie et la sédimentologie des crêtes montrent qu'elles se sont formées, en peu de temps, dans un milieu subaquatique de proximité glaciaire à la marge de la ligne d'ancrage de l'inlandsis en recul rapide. La stratigraphie des sédiments montre qu'il y a un rapport entre l'inlandsis ancré et les conditions subaquatiques à la marge.
Tous droits réservés @ Les Presses de l'Université de Montréal,2001

Ce document est protégé par la loi sur le droit d'auteur. L'utilisation des services d'Érudit (y compris la reproduction) est assujettie à sa politique d'utilisation que vous pouvez consulter en ligne.

https://apropos.erudit.org/fr/usagers/politique-dutilisation/ 


\title{
THE QUATERNARY SEDIMENTOLOGY AND STRATIGRAPHY OF SMALL, ICE-PROXIMAL, SUBAQUEOUS GROUNDING-LINE MORAINES IN THE CENTRAL NIAGARA PENINSULA, SOUTHERN ONTARIO
}

\author{
John MENZIES*, Departments of Earth Sciences and Geography, Brock University, St.Catharines, Ontario L2S 3A1.
}

ABSTRACT A series of small moraine ridges in the central Niagara Peninsula, southern Ontario, were investigated in order to understand the impact the retreating Laurentide Ice Sheet had on this area of Canada, in terms of the Quaternary sedimentology, stratigraphy and geomorphology. As the ice retreated from the Lake Erie Basin, the area was simultaneously inundated by a series of glacial lakes. The only surface expression of this retreat phase of the ice sheet are suites of small moraine ridges. The morphology, stratigraphy, and sedimentology of these ridges indicates that they were probably formed, over a short period of time, in an ice proximal subaqueous environment at the rapidly retreating grounding-line margin of the ice sheet. The sediments reveal a stratigraphy that indicates an association of grounded ice sheet and subaqueous marginal conditions.
RÉSUMÉ La sédimentologie et la stratigraphie du Quaternaire des petites moraines de limite d'ancrage proximales et sub-aquatiques, au centre de la péninsule du Niagara, dans le sud de l'Ontario. Une série de petites crêtes morainiques situées au centre de la péninsule du Niagara a été étudiée afin de préciser les effets du retrait de l'Inlandsis laurentidien dans cette région, en ce qui a trait à la sédimentologie, la stratigraphie et la géomorphologie du Quaternaire. Pendant le retrait même des glaces du bassin du lac Érié, la région a été inondée par une série de lacs glaciaires. La seule résultante morphologique de cette phase de retrait est l'édification de petites crêtes morainiques. La morphologie, la stratigraphie et la sédimentologie des crêtes montrent qu'elles se sont formées, en peu de temps, dans un milieu subaquatique de proximité glaciaire à la marge de la ligne d'ancrage de l'inlandsis en recul rapide. La stratigraphie des sédiments montre qu'il y a un rapport entre l'inlandsis ancré et les conditions subaquatiques à la marge.
ZUSAMMENFASSUNG Quartär-Sedimentation kleiner, Eis-proximalersubaquatischer Verankerungsmoränen im Zentrum der Niagara-Halbinsel, Süd-Ontario. Man hat eine Serie kleiner Moränenkämme im Zentrum der Niagara-Halbinsel, Süd-Ontario untersucht, um die Auswirkung, welche der Rückzug der laurentischen Eisdecke auf dieses Gebiet Kanadas hatte, zu verstehen bezüglich der Quartär-Sedimentation, Stratigraphie und Geomorphologie. Während das Eis sich aus dem Lake Erie-Becken zurückzog, wurde das Gebiet gleichzeitig durch eine Serie glazialer Seen überschwemmt. Die einzige Oberflächenspur dieser Rückzugsphase der Eisdecke sind Reihen kleiner Moränenkämme. Die Morphologie, Stratigraphie und Sedimentation dieser Kämme zeigen, dass sie wahrscheinlich in einem kurzen Zeitraum gebildet worden sind, in einer Eis-proximalen subaquatischen Umgebung am Rand der rasch zurückweichenden Verankerungslinie der Eisdecke. Die Stratigraphie der Sedimente zeigt, dass eine Beziehung zwischen der verankerten Eisdecke und den subaquatischen Bedingungen am Rand besteht. 


\section{INTRODUCTION}

At the close of the Late Wisconsinan, within the Lake Erie basin, large proglacial lakes developed coeval with the retreating Laurentide Ice Sheet (Karrow and Calkin, 1985; Karrow, 1989; MacKenzie, 1990; Dreimanis, 1995). As a consequence, the retreating ice sheet margin terminated in lake water in many places within the basin. The subject of this paper is to investigate the Quaternary stratigraphy, sedimentology and geomorphology of central Niagara Peninsula, in southern Ontario, Canada, in order to understand the consequences of this ice sheet retreat. Across the Niagara Peninsula a large number of small subparallel ridges can be observed that coincide approximately with the retreating margin of the Laurentide Ice Sheet (Løken and Leahy, 1964; Henderson, 1967; Feenstra, 1981; Dreimanis, 1995) (Fig. 1). In trying to understand the origin of these moraines, some importance was given to the interrelationship between the retreating ice margin and the rising lake waters (Henderson, 1967; Karrow and Calkin, 1985). In many instances the relationship between the ice margin and the proglacial lake must have affected the margin ice dynamics, considerably influencing ice basal velocities, mass balance gradients, ice thickness, basal shear stresses and subglacial/submarginal local sedimentary processes (Menzies, 1995). The latter processes manifesting as small moraine ridges at the edge of the retreating ice sheet.

\section{REGIONAL GEOLOGY AND STRATIGRAPHY}

An area was chosen to be investigated $4 \mathrm{~km}$ west of Bismark in the central part of the Niagara Peninsula, southern Ontario in what is generally termed the Haldimand Clay or Lake Plain; a broad undulating plain of glaciolacustrine sediments (Feenstra, 1981; Chapman and Putnam, 1984; Cooper et al., 1989) (Fig. 2). Following the maximum extent of Laurentide Ice Sheet during the Nissouri Stade (22.8 ka) (Late Wisconsinan) a general ice retreat began around $18 \mathrm{ka}$ (Hobson and Terasmae, 1969). At that time the Niagara Peninsula was estimated to be covered by approximately $800 \mathrm{~m}$ of ice (Fisher et al., 1985). This estimate of ice thickness is conjectural and where frozen bed conditions prevailed may have been much greater $\approx \geq 1200-1300 \mathrm{~m}$; and where deformable bed conditions existed much thinner $\approx \leq 500-600 \mathrm{~m}$ (Mathews, 1974; Boulton and Jones, 1979; Beget, 1986, 1987). As ice retreated north from the southern edge of the Lake Erie basin a vast proglacial lake system

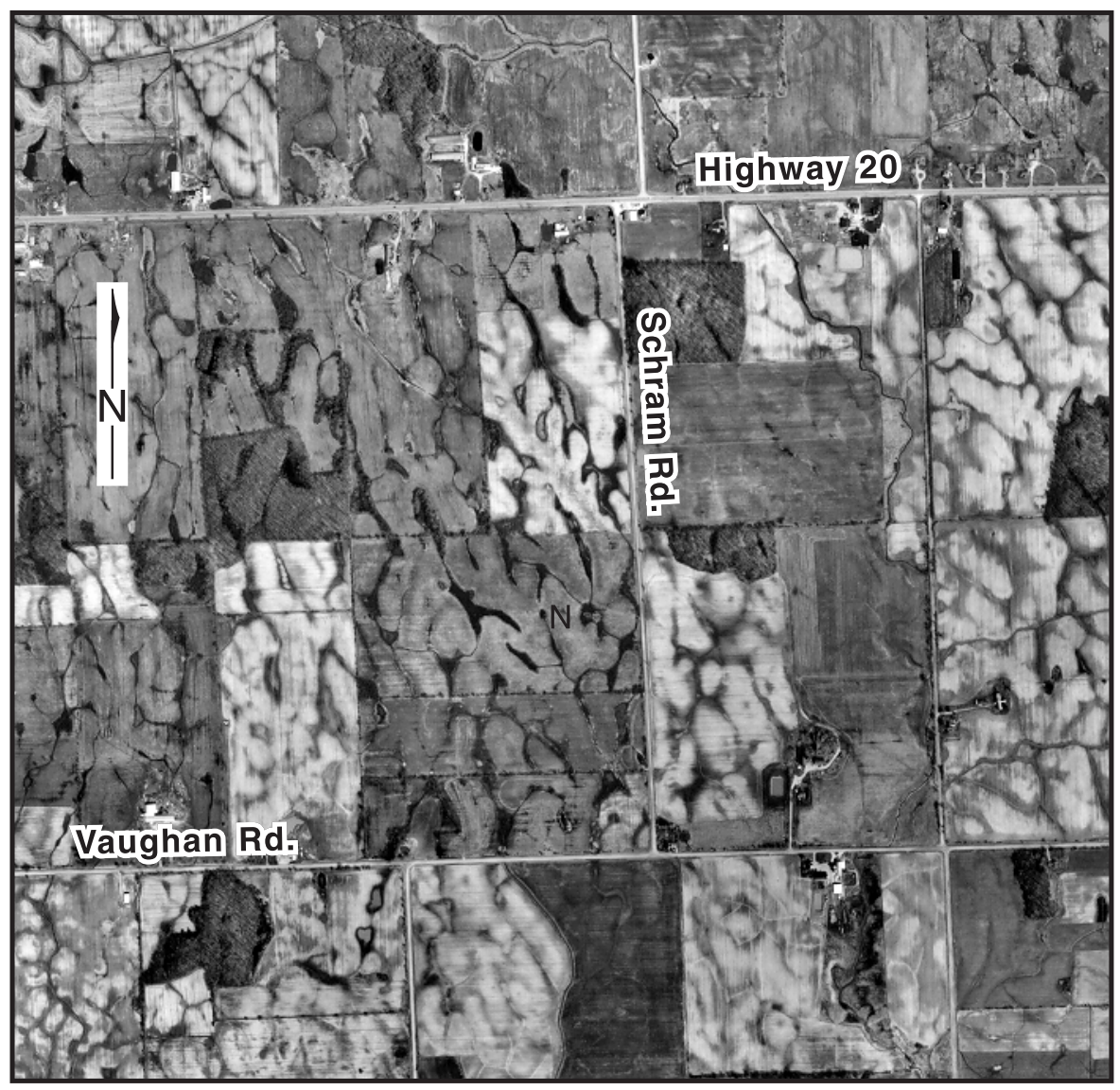

0
500

metres
FIGURE 1 Part of an aerial photograph of the Central Niagara Peninsula, southern Ontario, showing distinctive surface moraines (Aerial photograph \# 18-APR94003 L-9 87) (Permission granted to reproduce this photograph from the Municipality of Region Niagara, Thorold, Ontario).

Partie d'une photographe aérienne du centre de la péninsule du Niagara, qui montre la surface caractéristique des moraines (photographie aérienne $n^{\circ} 18$ APR-9003 L-987) (droit de reproduction accordé par la Municipality of Region Niagara, Thorold, Ontario). 


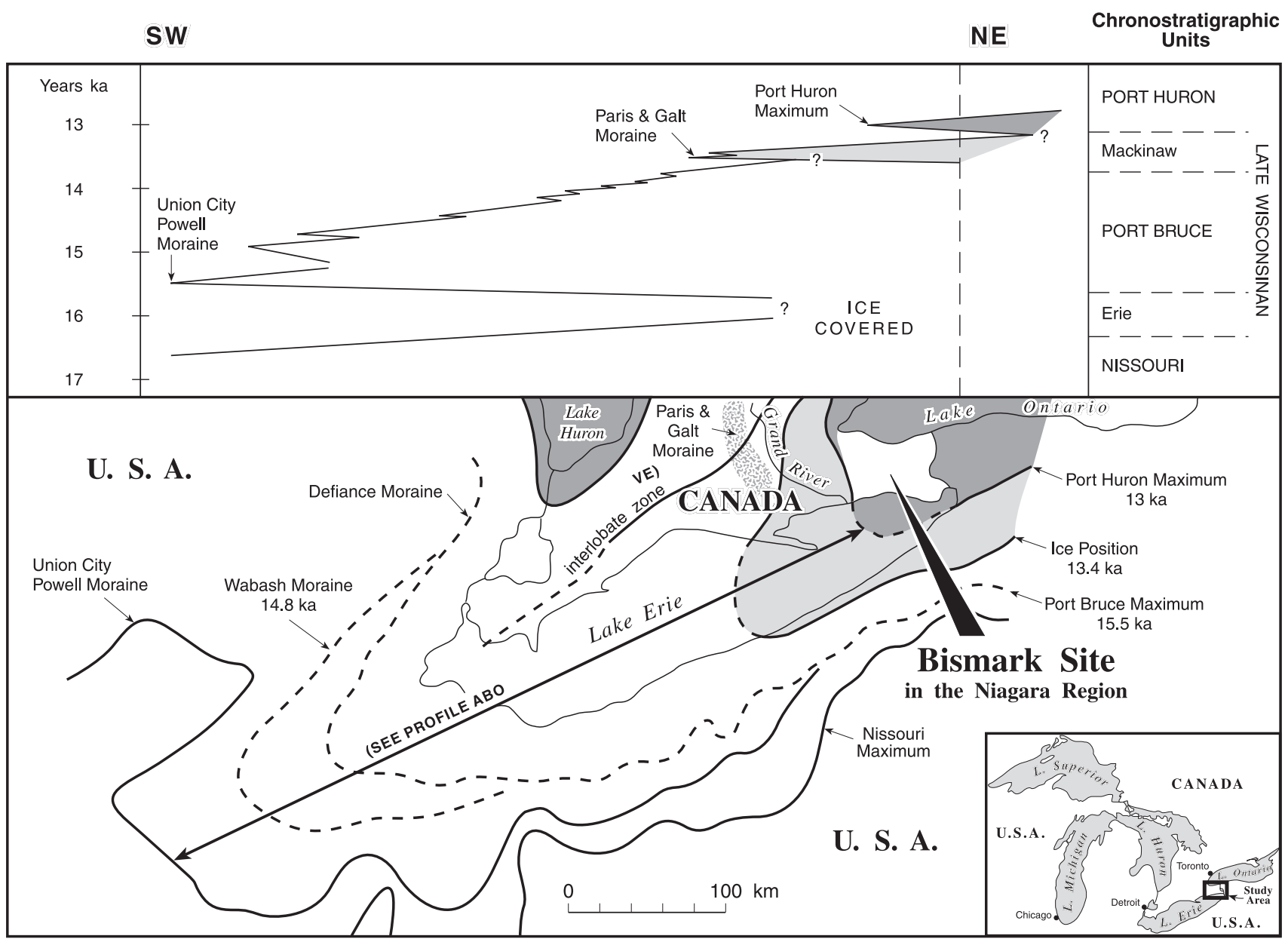

FIGURE 2. Laurentide Ice Sheet retreat stages across the northern Lake Erie basin and the Niagara Peninsula (after Karrow, 1989).

gradually developed in the basins of lakes Michigan, Erie and Huron (Calkin and Feenstra, 1985; Karrow, 1989). This lake system had no natural northward drainage route and initially spilled south via the Grand River, Michigan into the Mississippi-Missouri drainage basin. As ice retreated, short, and essentially regional, readvances took place all along the southern margin of the ice sheet. Some of these advances were of limited extent while others marked considerable extensions of ice south across the Lake Erie basin to Ohio (Dreimanis, 1983; Karrow and Calkin, 1985; Karrow, 1989).

In the Lake Erie basin, the first major retreat stage (the Erie Interstade) after the Nissouri Stadial appears to have occurred around $16 \mathrm{ka}$ (Fig. 2). Following this milder phase, ice advanced (the Port Bruce Stade) to occupy the Erie basin and deposit the Port Stanley Till (Dreimanis, 1995). As the Port Bruce ice retreated, proglacial lakes formed in the Erie basin; the first, and largest at that time, (Lake Maumee) appears to have been in existence by $\approx 14 \mathrm{ka}$ (Barnett, 1985; Sharpe and Barnett, 1985). At this time several of the large moraine systems that transect southern Ontario appear to have been deposited. By $\approx 13.5 \mathrm{ka}$ ice had largely
Les différents stades de retrait de l'Inlandsis laurentidien à travers la partie nord du bassin du lac Érié et la péninsule du Niagara (d'après Karrow, 1989).

retreated from the Erie and southern Huron basins although the Lake Ontario basin still remained ice covered. A major stillstand in ice retreat appears to have occurred at this time and those areas now uncovered from the ice experienced a short interstadial (the Mackinaw Interstade). Following the Mackinaw Interstade, ice again readvanced to a new frontal position during the subsequent Port Huron Stade at around $13 \mathrm{ka}$ and the Paris/Simcoe Moraine to the west of the Grand River near Simcoe was formed or enlarged. Following this ice advance, a generally eastward and then northward retreat of the ice occurred across the Niagara Peninsula interrupted by periodic stillstands and small terminal moraine construction (the moraines investigated in this paper). As ice retreated eastward into the Niagara Peninsula from a line approximately marked by the Grand River, a vast lake (Lake Whittlesey) followed in its immediate wake and may have caused the ice front to float (Løken and Leahy, 1964; Henderson, 1967). By at least $12.5 \mathrm{ka}$, ice appears to have retreated out of the Lake Erie basin and was to the north of the Niagara Peninsula in the Lake Ontario basin (Fig. 2) (Barnett, 1985; Calkin and Feenstra; 1985). It is at a period, 


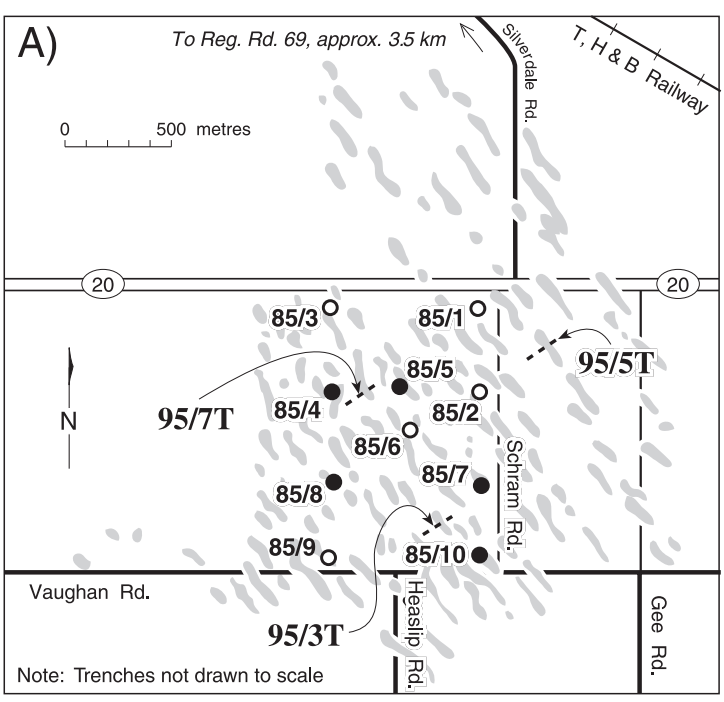

Ridge
Tegend
- Trench
Bores from inter-ridge areas
Bores from ridge areas

B)

\section{O BORELOG 85/1}

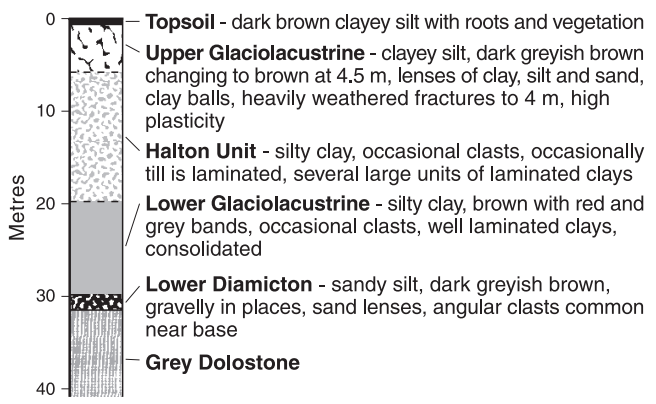

\section{- BORELOG $85 / 2$}

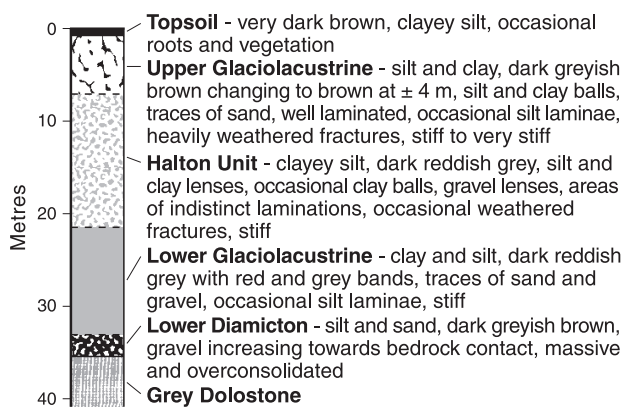

\section{O BORELOG $85 / 3$}

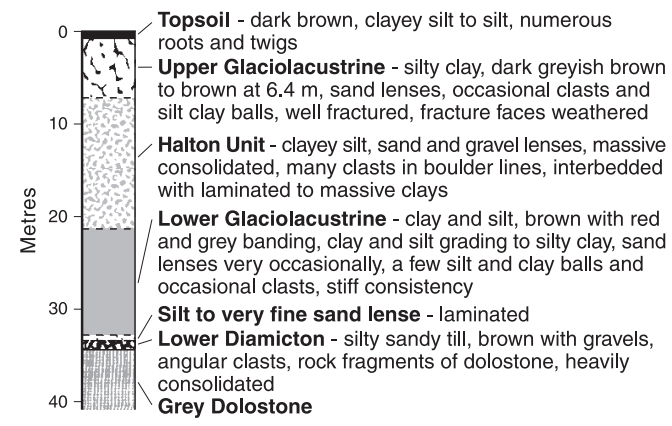

\section{- BORELOG 85/4}

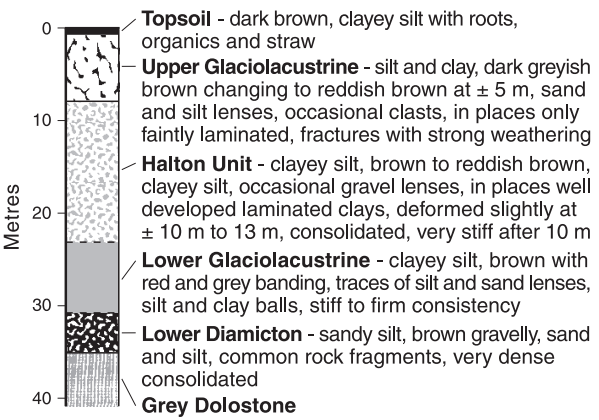

- BORELOG $85 / 5$

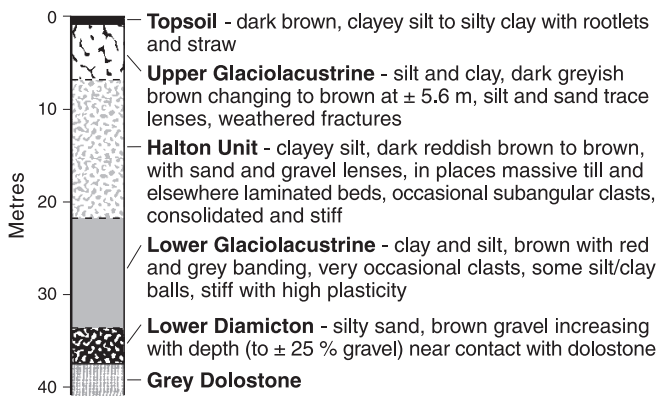

\section{○ BORELOG $85 / 6$}

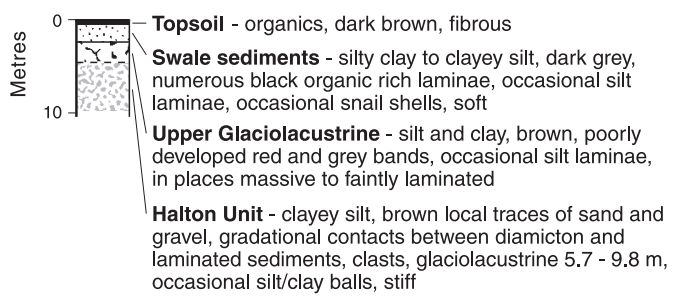




\section{- BORELOG 85/7}

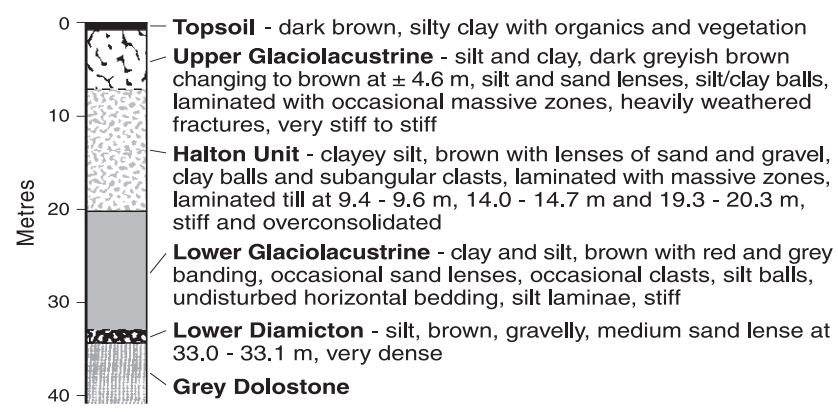

- BORELOG $85 / 8$

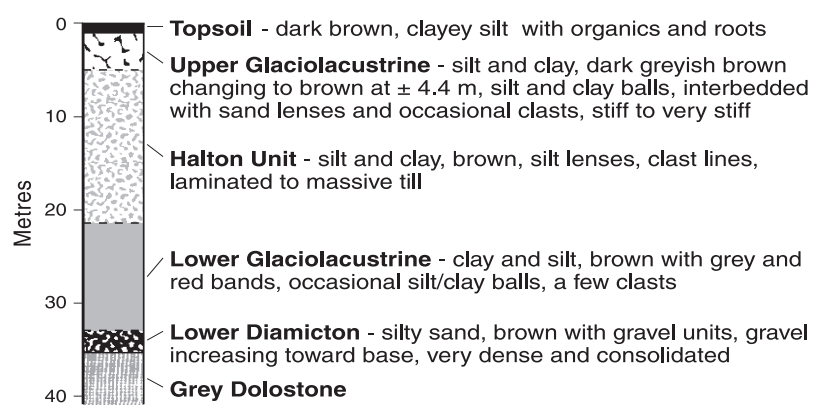

\section{○ BORELOG $85 / 9$}

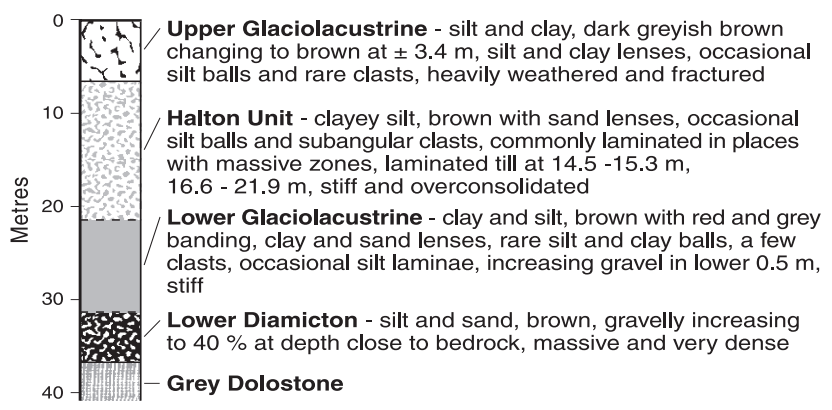

- BORELOG 85/10

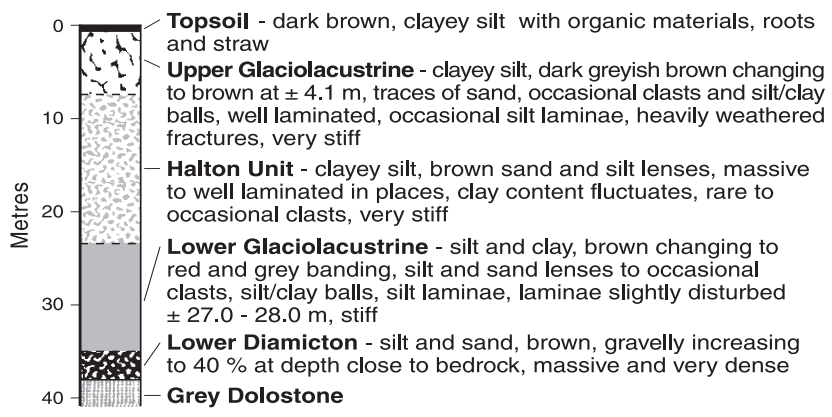

FIGURE 3. A) Geomorphic map in the Bismark area, Niagara Peninsula of moraine ridges (note trenches are not drawn to scale). B) Glacial Stratigraphy in central Niagara Peninsula, southern Ontario, as logged in ten boreholes (modified from Gartner Lee Associates, 1987) (note position of borelogs on or off the moraine ridges).

A) Carte géomorphologique des crêtes monrainiques de la région de Bismark, dans la péninsule du Niagara (les tranchées ne sont pas à l'échelle). B) La stratigraphie glaciaire au centre de la péninsule du Niagara, au sud de l'Ontario, telle que révélée par dix sondages (modifié de Gartner Lee Associates, 1987) (noter l'emplacement des trous sur les crêtes morainiques ou à côté).

prior to the final ice retreat from the Niagara Peninsula (pre $12.5 \mathrm{ka}$ ), that the ridges in the Peninsula were formed. It is difficult to estimate actual water depths at the lake/ice front margin where the ridges may have formed since ice margin thickness, topographic variation and the rate of proglacial lake water incursion would have varied enormously. Any calculated water depths would be minimum depths and might not reflect the actual depths. However, as will be argued below, it seems possible that the ridges were formed in the late stages of ice retreat from this area within a relatively shallow water depth of less that $100 \mathrm{~m}$ (Vincent and Hardy, 1979; Beaudry and Prichonnet, 1995).

\section{REGIONAL STRATIGRAPHY AND SEDIMENTOLOGY}

The data that form the basis of this paper derive, in part, from work done on a proposed waste disposal site by Gartner Lee Associates and made available to the author by the company, from data collected by the author from over 100 bore cores donated by Gartner Lee Associates to Brock University, and by field and laboratory work conducted by the author. The stratigraphic subdivision of glacial sediments package in the Niagara Peninsula is illustrated in Figure 3. Stratigraphic and sedimentological studies in the past (Owen, 1969, 1972; Feenstra, 1981) have identified four major glacial or glacially associated litho-stratigraphic units (from bottom to top) viz., a lower till; a lower glaciolacustrine unit; an upper till; and an upper glaciolacustrine unit. The lower till is thought to represent the Port Bruce Stade and is equivalent to the more westerly known Port Stanley Till or Wentworth Till (Dreimanis and Karrow, 1972; Karrow, 1989). The lower glaciolacustrine unit is regarded as being of Mackinaw Interstade age; the upper till or Halton Till is thought to be of the Port Huron Stade; and the upper glaciolacustrine unit to be of the Two Creeks Interstade and later postglacial age (Feenstra, 1981; Gartner Lee Associates, 1987). The only modification to this stratigraphic system, adopted in the present paper and previously noted by Cooper et al. (1989), was in defining the upper till as the Halton Unit rather than Halton Till (see discussion below).

\section{LOWER DIAMICTON UNIT}

This sediment would appear to have been deposited in situ from the evidence of increasing gravel with proximity to the underlying bedrock. A few random small sand and gravel lenses exist within the diamicton unit; this sediment is a typical 
clast-rich, matrix-dominant diamicton of variable clast content from both local and exotic sources.

The lower contact with bedrock is typical of a basal diamicton where erosion and short-distance transport of bedrock have occurred. The upper contact, however, is gradational with a fine-grained transitional zone noted in borelog descriptions. In hand examination of cores (Fig. 3), the contact between the Lower Diamicton Unit and the overlying Lower Glaciolacustrine Unit was difficult to detect, an almost imperceptible change occurred from clast-rich, matrix-dominant diamicton to a matrix-dominant rhythmically banded clay-silt over a 2-3 m vertical zone.

\section{LOWER GLACIOLACUSTRINE UNIT}

This unit is best considered as a set of subfacies units; the dominant facies is a rhythmically banded clay-silt that exhibits fine laminae (Fig. 3). Four subfacies units, described on a regional scale by Feenstra (1981), can be detected viz., 1) a lower silt and fine sand unit; 2) a lower laminated siltclay unit; 3) a massive diamictic silt clay unit; and 4) an upper laminated silt-clay unit. Whether these subfacies units can be considered as intercalated units, or separate facies units remains contentious. The lower and upper stratigraphic contacts are generally gradual with no marked contact seen in hand specimens examined. However, sharp contacts have been observed in some bore cores where sharp colour contrasts from brown to greyish brown are noted between this unit and the overlying Halton Unit (Fig. 3). Occasional clasts, typically subrounded to subangular, are detectable but no dropstone structures were noted.

\section{HALTON UNIT}

This is the thickest unit of glacial sediments through-out the central Niagara Peninsula and forms the core unit within the ridges (Fig. 3). Once viewed as a single till unit, it is now perceived as a composite unit of associated subfacies. This unit is dominantly a matrix-supported, often massive, diamicton possibly better described as a glacial diamicton mélange (Menzies, 1989; Menzies, 1990a; Menzies and Shilts, 1996). The term glacial mélange perhaps best typifies a facies unit composed of a variety of subfacies units that appear to be intercalated with each other and emplaced syndepositionally. The term also carries with it the direct implication of intrastratal, shear-induced deformation during or immediately before deposition, not to be confused with glaciotectonic deformation that is typically interstratal deformation (Van der Wateren, 1995). Other subfacies detected include stratified sand and silt units, gravel lenses, and laminated clays and silts (Bores \# 85/2, 85/4, 85/9). In some cases these units are of considerable thickness within the Halton Unit sediment package $(>2 \mathrm{~m}$ ), while in other places they may be thin $(<50 \mathrm{~cm})$ or absent.

The lower contact with the Lower Glaciolacustrine Unit, as already noted, is often gradational, only a matrix colour change from brown to greyish brown, in some cases, defines what appears to be a litho-stratigraphic boundary. The upper contact is equally imperceptible. In hand specimen, from examination of cores, this upper contact was difficult to recog- nize (Fig. 3). Geotechnical changes have been noted at the upper contact largely as a result of grain size variations. Small fractures extending down from the Upper Glaciolacustrine Unit commonly occur close to the upper surface of this unit.

\section{UPPER GLACIOLACUSTRINE UNIT}

This sediment unit is commonly found at or near the ground surface through-out this part of the Lake Erie basin in the Niagara Peninsula. This is a massive, matrix-supported, clayey silt or silty clay with rhythmically banded laminae (Fig. 3). A few inclusions of massive clay units occur within this unit as do occasional clasts and clay/silt balls (e.g., Bore \#85/3). The lower contact with the Halton Unit, as noted above, is typically gradational. Within this unit there are extensive fractures and joints. The commonest depth for fractures occurs within the soil weathering zone close to the surface at $<3 \mathrm{~m}$; however, occasional fractures penetrate to 5-6 m. It should be noted that only evidence of brittle deformation structures were detected in this unit; there being no evidence of ductile deformation structures (van der Meer, 1996; Menzies, 1998, 2000).

\section{REGIONAL SEDIMENT LITHOFACIES ASSOCIATIONS}

There is a general consensus concerning the glacial and postglacial stratigraphy in central Niagara Peninsula south of the Niagara Escarpment (Menzies and Taylor, 1999) as illustrated in examples of borelogs (Fig. 3). However, a marked spatial variability does exist in that certain units appear to be absent in some areas of the Niagara Peninsula. For example, to the west of the site in the Caledonia area within a small drumlin field (Menzies, 1986), and to the south of the site at Mohawk Bay, the Lower Glaciolacustrine Unit is absent (Menzies, 1990b). It seems likely this localised spatial variability is a function of ice dynamics and the vagaries of glacigenic sediment deposition.

\section{RIDGE MORPHOLOGY}

In many parts of central Niagara the dominant surface geomorphic expression are low, sub-parallel ridges that cross the area in a roughly north, northwest to south, southeast direction parallel to the once retreating ice sheet margin (Figs. 1 and 3). As Figure 3 illustrates, these ridges are typically short in length and crudely aligned. The ridges reach heights of between approximately 1 to $2.5 \mathrm{~m}$, and extend for about 5 to $350 \mathrm{~m}$ in length, and have a crest-to-crest spacing of approximately 10 to $200 \mathrm{~m}$. From trial pits dug in the vicinity of these ridges it seems likely that postglacial subaerial erosion and mass movement depositing colluvium in the inter-ridge depressions has reduced the overall relief of many of the ridges (Figs. 3 and 4).

\section{RIDGE SEDIMENTOLOGY}

Examination of ridges using bore cores and trial pits has resulted in a detailed stratigraphy of the glacial sediment package within the ridges (Figs. 3 and 4). The structural 
expression, for example, of the above sediments in the ridges near Bismark takes the form of relatively undeformed layers of Upper Glaciolacustrine units overlying the Halton Unit. In many places recent colluvium fills in the depressions between the ridges. It can be seen from Figure 4 that there is in some places a slight increase in thickness of the Upper Glaciolacustrine Unit over the crests of the ridges. The Halton Unit, also in places, seems to exhibit a thickening beneath ridge crests.

From Figure 4, examples of three cross-sections illustrate the general stratigraphy within the ridges. In most inter-ridge hollows a fairly thick layer of organic muds and peat are to be found, often, as in the case of Pit 95/3T, overlying a considerable thickness of colluvial sediments. In many cases, extensive fractures extend down from the ground surface but, more typically, extend from within the Upper Glaciolacustrine Unit into the underlying Halton Unit (note Pit 95/5T). As noted in the trial pit cross sections, the topographic expression of the moraine ridge is composed of Upper Glaciolacustrine Unit and Halton Unit sediments. Ductile deformation structures were not observed in either lithofacies unit within the ridges.

\section{GENERAL INTERPRETATION OF SEDIMENTS IN THE CENTRAL NIAGARA PENINSULA}

At the bedrock contact the Lower Diamicton Unit appears to be a typical subglacial till since the relationship with the underlying bedrock exhibits characteristics of lodgement style processes with rip-up clasts entrained in the lower section of the till, localised bedrock dominant but with clasts of an exotic provenance, overconsolidation, and low porosity (Dreimanis, 1988; Menzies and Taylor,1999) (Fig. 5). The Lower Diamicton Unit appears to exhibit typical high density, consolidated characteristics consistent with in situ deposition at the subglacial interface, at least for the lower part of the unit close to bedrock. At the top of this unit, as demonstrated by the gradational sedimentary contact and non-erosional interface, a transition from subglacial/subaquatic conditions to truly subaquatic conditions may have occurred over some length of time. It is likely in that event that a reducing stress/ strain field occurred as the ice lifted off its bed and a floating or ice proximal lacustrine environment developed.

The Lower Glaciolacustrine Unit is a laminated sediment with a limited clast content; individual laminae exhibit slight disruption in a few places from small clasts and a consistent grain size dominantly of silts and clays. Occasionally as noted in the borelogs, coarser, diamictic sediments are encountered. In general, it is likely that this unit represents a series of ice-proximal subaquatic sediments with subglacial debris tongues interfingered into it (Brodzikowski and Van Loon, 1991; King et al., 1991); or the unit is a composite iceproximal subaquatic mélange of the type similar to that described by Talbot and Von Brunn (1987) and Menzies (1990a) (Fig. 5). Within the Lower Glaciolacustrine Unit the only stress of significance would have been due to occasional sediment dumping in the form of clots and dropstones. Over time, in what was probably a rapidly
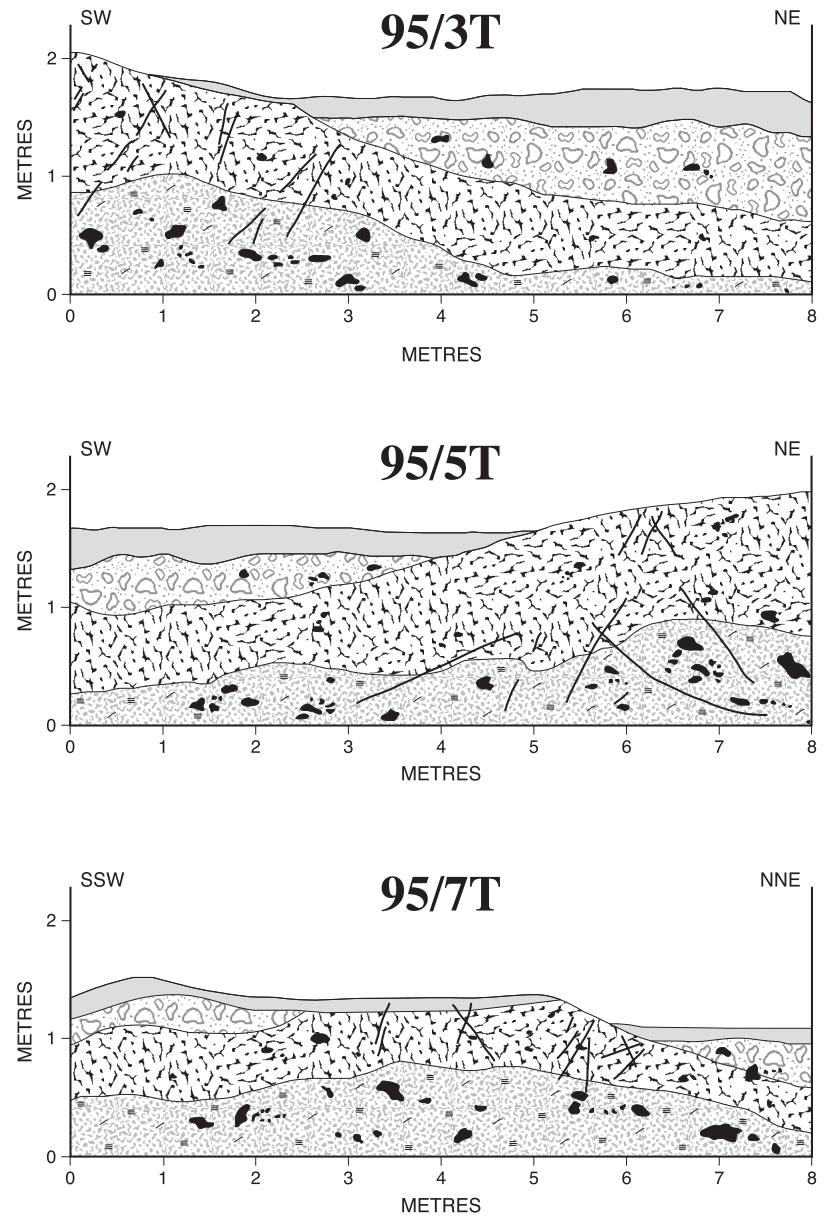

Legend

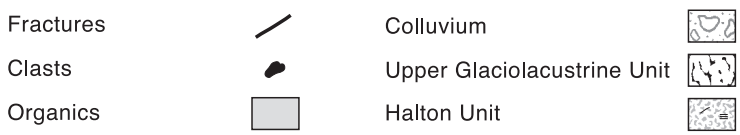

FIGURE 4. Stratigraphic cross-sections through three moraine ridges (note location, depth and 2-dimensional geometry of fractures).

Coupes stratigraphiques transversales dans trois crêtes morainiques (noter l'emplacement, la profondeur et la géométrie bidimensionnelle des fractures).

sedimenting environment, compression and subsequent dewatering from overburden sediments must have taken place (Solheim et al., 1990). This form of stress consolidation, however, would have been relatively slow and typical of undrained consolidation such that structural and grain-tograin adjustments may have occurred with relatively minor structural discontinuities developing other than along natural bedding planes and over short distances $(<1 \mathrm{~m}$ ) (Woodworth-Lynas, 1996). Close to the upper contact with the Halton Unit a change in stress/strain conditions appears to have occurred as ice readvanced across this section of the Lake Erie basin. The exact nature of this advance would appear, from all the interconnected evidence, to indicate a floating or 


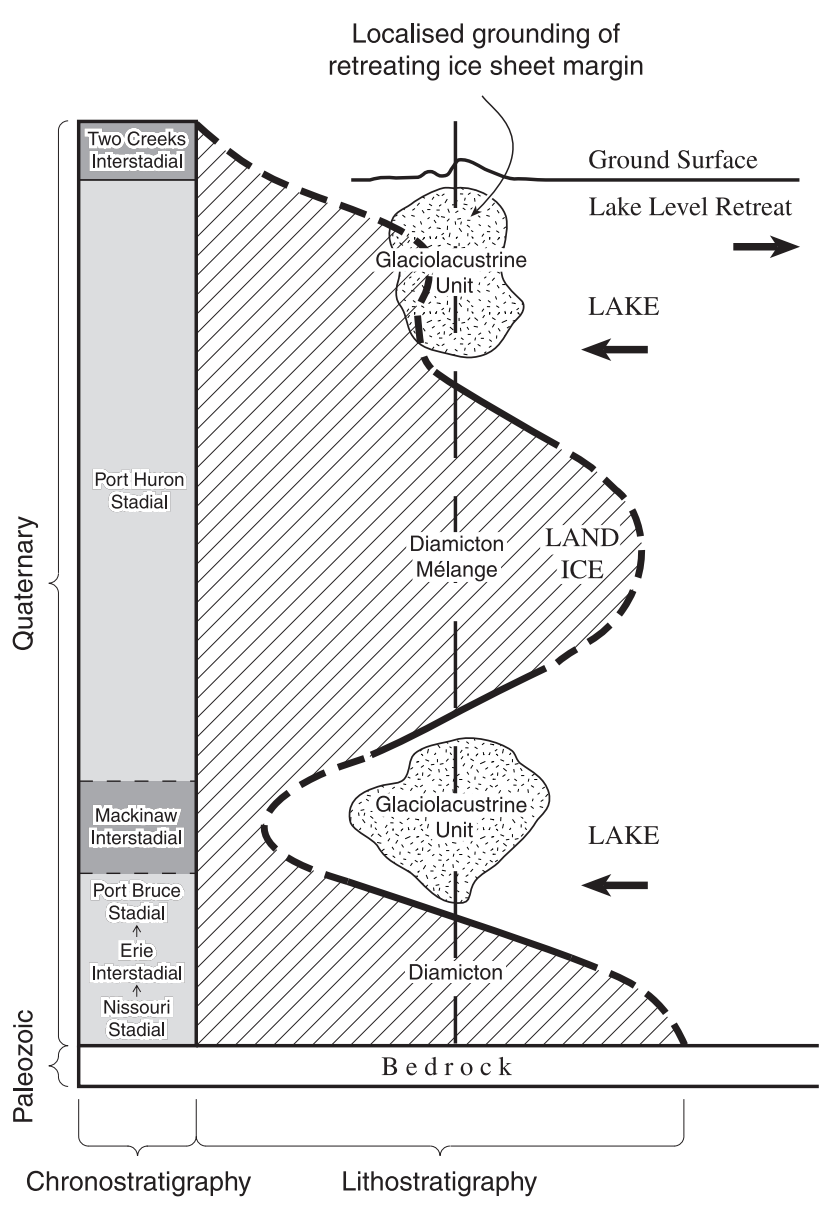

FIGURE 5. Interpreted chronostratigraphic stages of sedimentation for central Niagara Region (Menzies and Taylor, 1999).

Interprétation des différentes étapes chronostratigraphiques de la sédimentation dans la région du centre du Niagara (Menzies et Taylor, 1999).

episodically, but localised, grounded ice margin in which both glaciolacustrine and subglacial/ice-proximal, proglacial sedimentation occurred. Consolidation, although occurring, was not high at the sedimentary contact between the Lower Glaciolacustrine Unit and Halton Unit.

The Halton Unit is, as noted previously, a more complex series of sediment units that may combine both terrigenous and subaquatic subfacies elements (Fig. 5). The presence of a large number of subunits of laminated sediment, clast-supported units, and silt bed units may indicate a polymictic formative process where different facies units have been incorporated during transport prior to deposition; or the inclusion of subfacies units due to spatially variable micro-environments occurring randomly during the general diamicton deposition phase. This latter scenario does not carry any implications of shear induced mixing and boudinage-style intercalation. However, another interpretation was suggested by Feenstra (1981) who recognised five separate units in which three waterlain till units were sandwiched between two glaciolacustrine units (Dreimanis, 1988). Throughout the Halton Unit, a range of stress events appears to have occurred possibly due to temporary basal ice grounding or the nature of the ice/bed interface conditions altering from one mode of deposition to another. Towards the top of the Halton Unit there is a consistently increasing consolidation effect, perhaps indicative of overlying grounded ice developing or instigating minor 'lift-off' moraine ridges. The transition from the Halton Unit to the Upper Glaciolacustrine Unit may indicate a transition from a subglacial/ice proximal subaquatic environment to increasingly more distal subaquatic conditions (Fig. 5).

Finally, the Upper Glaciolacustrine Unit appears to mark the transition between, in its lowest sections, a subaquatic increasingly distal glacially-derived sediment source to postglacial subaquatic sediments in its upper sections (Fig. 5). This unit drapes over the Halton Unit and has been subject to several different consolidating effects. Primarily, the effect of floating ice and moraine ridge development would appear to indicate localised but differential consolidation, but, from the size and number of moraine ridges, the stress events would appear to have been relatively short and of low stress levels under thinning ice within a marginal location in a lake basin.

In terms of glacial chronology, Figure 5 illustrates a possible general interpretation of glacial events and sediment depositional phases from bedrock to the ground surface in the central Niagara Peninsula. The chronostratigraphic relationships shown in Figure 5 depend upon the interplay between the advance and retreat of the Laurentide lce Sheet in the Niagara Peninsula and the expansion and contraction of the glacial lake systems (for an extended discussion see Menzies and Taylor, 1999).

\section{RIDGE FORMATION}

The possible interpretations for ridge formation range from small, terrigenous, terminal, possibly annual, retreat moraines, Push moraines (Maarleveld, 1983), squeezed 'Crevasse-fill' ridges (Sharp, 1985; Aber et al., 1989), Rogen moraines (Bouchard, 1989; Lundqvist, 1989), subaquatic 'LiftOff' moraines (King and Fader, 1986; Sættem, 1990; King et al., 1991), De Geer or Washboard moraines (Elson, 1957, 1968; Andrews and Smithson, 1966; Aartolahti, 1972; Punkari, 1980; Powell, 1981; Aylsworth and Shilts, 1989; Zilliacus, 1989; Solheim et al., 1990; Beaudry and Prichonnet, 1995), to ice-proximal, subaqueous grounding-line moraines.

Several researchers have commented upon these ridges in southern Ontario (Gwynne, 1942; Løken and Leahy, 1964; Henderson, 1967; Feenstra, 1981; Dreimanis, 1995). The question of their origin centres upon whether: a) these ridges were formed beneath an active ice sheet in advance or retreat mode and were then subsequently overlain with glaciolacustrine sediment; or alternately, b) were the ridges formed penecontemporaneously with the deposition of the glaciolacustrine sediments or very soon afterward? The moraine ridges, for example, noted by Dreimanis (1995), near St. Thomas in southwestern Ontario, are substantially much larger in overall dimensions and topographic expression and therefore may not be comparable in origin to the much smaller topographically-muted ridges in central Niagara. 
FIGURE 6. Schematic representation of how ridges may have formed in a glacial lake during general ice sheet retreat (note diagram not drawn to scale and lake levels assumed constant over short time period).

Représentation schématique de l'édification des crêtes dans un lac glaciel au cours du retrait de l'inlandsis (noter que le diagramme n'est pas à l'échelle et que le niveau des lacs est considérée comme ayant été constant pendant une courte période).

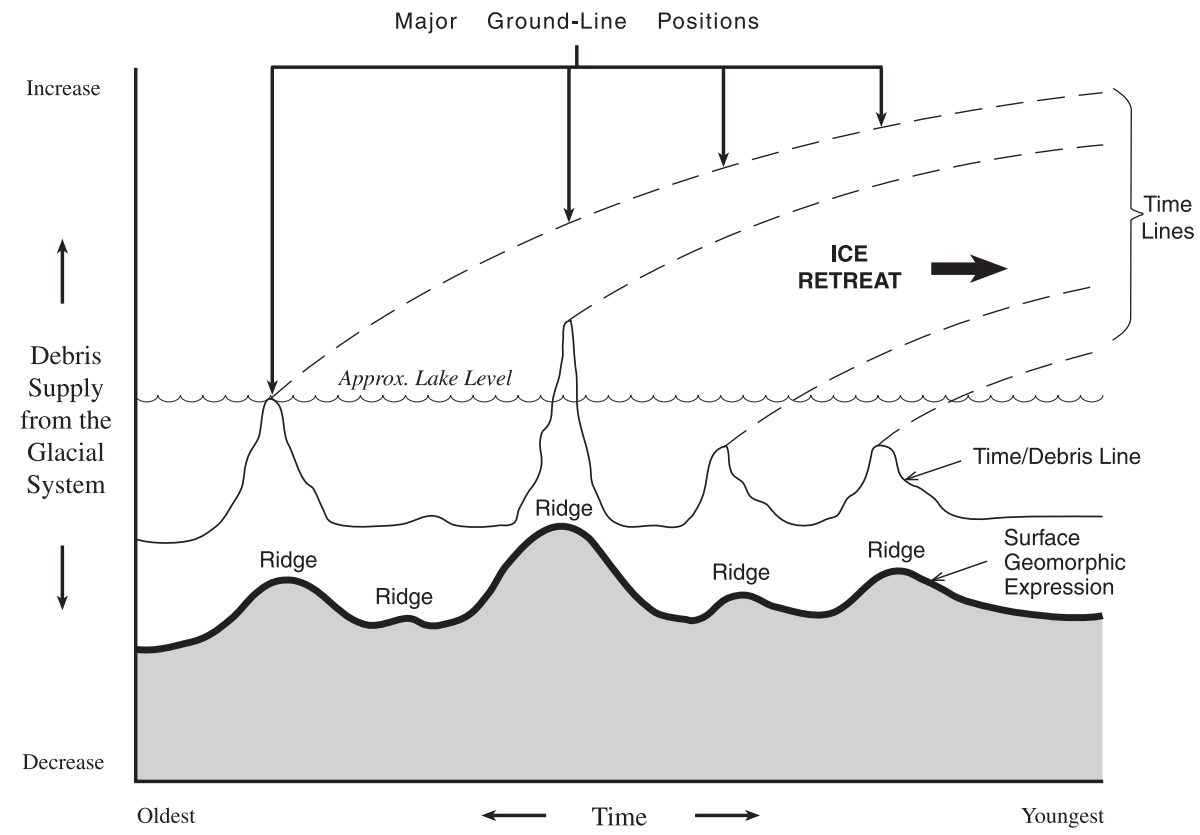

A classification of moraine ridges within such subaquatic/ subglacial environments has been put forward by King and Fader (1986) who distinguish three major ridge type groups within either ice advance or retreat phases viz., A) linear; B) tabular and hummocky, and $C$ ) lift-off. In general, all the moraine ridges defined in groups $A$ and $B$ are dimensionally large and typically formed in relatively deep water; whereas type $C$ are moraine ridges similar to those in central Niagara formed in water normally less than $100 \mathrm{~m}$ in depth.

The ridges in central Niagara have certain general characteristics that require explanation. First, they are small, relatively short in length and rarely more than $3 \mathrm{~m}$ in height. Secondly, the ridges are crudely parallel to each other and seem to coincide with the general orientation of the retreating ice sheet margin in the local area. Thirdly, from the internal sedimentology of the ridges there appears to be no evidence of deformation in the form of squeeze structures or associated lateral stress application. Given these constraints, it is proposed here that the ridges were morainic features created by differential "dumping" by localised deposition of saturated glacial sediments at the retreating margin of a grounded ice sheet. It is suggested that with general retreat of the ice margin and occasional stillstands, slightly higher amounts of the Halton Unit were differentially deposited and subsequent draping of the Upper Glaciolacustrine Unit emphasised the localised thickenings into topographic ridges.

At such a retreating margin three distinct mechanisms are involved viz., i) at the grounding-line debris issues from the subglacial/englacial environment; ii) with the rise and fall of the ice (due to changing ice thickness and water depths) at the grounding-line, stress transmission to the glacier bed by the overlying ice occurs causing differential compaction of already deposited sediment in localised zones parallel to the ice margin front and transverse to the general ice sheet flow direction; and iii) squeezing of basal debris into basal cre- vasse cavities formed as result of flexure of basal ice fracturing due to fluctuating lake levels (Zilliacus, 1989). Since there is no evidence of any form of deformation of the sediments (Halton nor Upper Glaciolacutrine) neither of the latter two processes seems to have been operative in central Niagara.

Close to an ice sheet grounding-line several sources of sediment may emanate from up-ice viz., subglacial lodgement, and melt-out tills; englacial debris in the form of melt-out till; proglacial subaquatic debris flow till; and subglacial deformable debris in the form of a 'till delta' (Gravenor et al., 1984; Alley et al., 1986, 1987; Drewry, 1986; Powell, 1988, 1990; Dowdeswell and Scourse, 1990; Brodzikowski and Van Loon, 1991). If the ice sheet remains for any length of time at a particular locale, then debris from any of these sources may build up a proximal moraine ridge oriented locally parallel to the ice front margin and transverse to the general ice sheet flow direction (Bennett and Boulton, 1993)(Fig. 6). Thus in retreat, if punctuated by a series of short stillstands, a sequential set of moraine ridges will form that are the manifestation of the length of time the ice sheet remained at a particular point in the landscape, the volume of debris discharged at that point in space, and the nature of the ice margin itself (Fig. 6). The debris may consist of sediment of several different lithofacies types viz., rain-out debris and iceberg debris 'dumping' from within the lake (Eyles and Miall, 1984; Thomas and Connell, 1985); lodged till; melt-out till laid down by gradual melting (this type of till is thought unlikely to form within this particular environment - see Benn, 1989; Menzies, 1989, 1990a); and as mélange-type sediment moving from the subglacial to the immediate subaquatic proglacial where it may be injected into the grounding-line position under high porewater pressures and relatively low shear stresses.

From the above discussion, it seems likely that individual moraine ridges, parallel to the ice front margin and transverse to the general ice sheet flow direction, were the result of local 
grounding-line stillstands and/or incipient buoyancy of the ice margin in a grounding-zone (King et al., 1991). Based upon the dimensions of the individual moraine ridges and the crestto-crest distances, it would appear that each moraine ridge formed over a relatively short time period during a relatively fast retreat of the ice margin across this part of central Niagara. The crest-to-crest spacing may indicate either short punctuated stillstands where at each pause debris could accumulate; or alternately, the spacing illustrates the level of stress deformation suffered by the underlying sediments such that large moraine ridges indicate larger stresses occurring over a wider longitudinal section of terrain and vice versa. From the general orientation of the moraine ridges transverse to the general ice sheet flow direction, the ice grounded margin appears to have swung slightly from a NNW-SSE direction toward a W-E alignment. Based upon the size and spacing of the moraine ridges, the ice appears to have retreated fairly rapidly across the area but slowed down in retreat toward the north of Highway 20 remaining at each moraine ridge site for somewhat longer periods of time (Bennet and Boulton, 1993). As the ice retreated north of the site, the terrain surface rises and lake water depth would shallow slightly, both factors that would, perhaps, reduce the rate of ice retreat and increase sediment thickness through more prolonged "dumping" at one location. As a consequence the ridges would be larger and spaced greater distances apart.

An alternate explanation for the change in orientation and size of the moraine ridges may be that this area was a calving embayment within the margin of the floating ice grounding-line and, with time and differential loss of ice, a new margin was established to the north with greater ice thicknesses, slower retreat rates and greater debris flux (King et al., 1991).

\section{CONCLUSION}

It is apparent that the central part of the Niagara Peninsula exhibits characteristics typical of a subglacial/proximal subaquatic set of fluctuating environments. These environments dominated at the time of sediment deposition and, in the final stages of deposition, the effect of a partially floating/ grounded ice sheet margin, rapid retreat and localised "dumping" of sediment led to a sediment pile formed parallel to the ice margin and transverse to ice sheet flow direction, leading to the development of a series of discontinuous, subparallel, moraine ridges. The myriad of small moraine ridges are regarded as evidence of the ice margin grounding during the general rapid retreat of the Laurentide Ice Sheet across the Niagara Peninsula.

\section{ACKNOWLEDGEMENTS}

The author wishes to thank Gartner Lee Associates of Markham, Ontario for making data available and to donating bore cores for archiving at Brock University for further long term analyses. The critical and valued comments on an earlier version of this paper by Luc Beaudry and Bob Gilbert are enormously appreciated. Also thanks to the Municipality of Region Niagara for permission to reproduce, in part, an aerial photograph, and to Loris Gasparotto for his skills as cartographer. This study was supported, in part, by NSERC Research Fund Grant A6900.

\section{REFERENCES}

Aartolahti, T., 1972. On deglaciation in southern and western Finland. Fennia, 114: 1-84

Aber, J.S., Croot, D.G. and Fenton, M.M., 1989. Glaciotectonic Landforms and Structures. Kluwer Academic Publisher, Boston, 200 p.

Alley, R.B., Blankenship, D.D., Bentley, C.R. and Rooney, S.T., 1986. Deformation of till beneath ice stream B, West Antarctica. Nature, 322: 5759

Alley, R.B., Blankenship, D.D., Rooney, S.T. and Bentley, C.R., 1987. Continuous till deformation beneath ice sheets. International Association of Hydrological Sciences, Publication 170: 81-91.

Andrews, J.T. and Smithson, B.B., 1966. Till fabrics of the cross-valley moraines north-central Baffin Island, North West Territories, Canada. Geological Society of America Bulletin, 77: 271-290.

Aylsworth, J.M. and Shilts, W.W., 1989. Bedforms of the Keewatin Ice Sheet, Canada. Sedimentary Geology, 62: 407-428.

Barnett, P.J., 1985. Glacial retreat and lake levels, north-central Lake Erie basin, Ontario, p. 185-194. In P.F. Karrow and P.E. Calkin, eds., Quaternary Evolution of the Great Lakes. Geological Association of Canada Spec. Publ. 30, St. John's, 258 p.

Beaudry, L.M. and Prichonnet, G. 1995. Formation of De Geer Moraines deposited subglacially, Central Québec. Géographie physique et Quaternaire, 49: 337-361.

Beget, J.E., 1986. Modelling the influence of till rheology on the flow and profile of the Lake Michigan lobe, southern Laurentide ice sheet, U.S.A. Journal of Glaciology, 32: 235-241.

1987. Low profile of the northwest Laurentide ice sheet. Arctic and Alpine Research, 19: 81-88.

Benn, D.I., 1989. Controls on sedimentation in a late Devensian ice-dammed lake, Achnasheen, Scotland. Boreas, 18: 31-42.

Bennett, M.R. and Boulton, G.S., 1993. A reinterpretation of Scottish 'hummocky moraine' and its significance for the deglaciation of the Scottish Highlands during the Younger Dryas or Loch Lomond Stadial. Geological Magazine, 130: 301-318.

Bouchard, M.A., 1989. Subglacial landforms and deposits in central and northern Québec, Canada, with emphasis on Rogen moraines. Sedimentary Geology, 62: 293-308.

Boulton, G.S. and Jones, A.S., 1979. Stability of temperate ice caps and ice sheets resting on beds of deformable sediment. Journal of Glaciology, 24: 29-43.

Brodzikowski, K. and Van Loon, A.J., 1991. Glacigenic Sediments. Developments in Sedimentology, 49. Elsevier Science Publications, Amsterdam. 674 p.

Calkin, P.E. and Feenstra, B.H., 1985. Evolution of the Erie-Basin Great Lakes, p. 149-170. In P.F. Karrow and P.E. Calkin, eds., Quaternary Evolution of the Great Lakes. Geological Association of Canada Spec. Publ. 30, St. John's, $258 \mathrm{p}$.

Chapman, L.J. and Putnam, D.F., 1984. The Physiography of Southern Ontario. 3rd edition Ontario Geological Survey Special Volume, 2, Toronto, $270 \mathrm{p}$.

Cooper, A.J., Funk, G.H. and Anderson, E.G., 1989. Using Quaternary stratigraphy to help locate a hazardous waste treatment site, p. 1-13. In E.F.J. De Mulder and B.P. Hageman, eds., Applied Quaternary Research. A.A. Balkema Publishers, Rotterdam, $185 \mathrm{p}$.

Dowdeswell, J.A. and Scourse, J.D., 1990. Glaciomarine Environments: Processes and Sediments. Geological Society Special Publication No. 53, London, $423 \mathrm{p}$.

Dreimanis, A., 1983. Penecontemporaneous partial disaggregation and/or resedimentation during the formation and deposition of subglacial till. Acta Geologica Hispanica, 18: 153-160. 
1988. Tills: their genetic terminology and classification, p. 17-83. In R.P. Goldthwait and C.L. Matsch, eds., Genetic classification of glacigenic deposits. A.A. Balkema Publishers, Rotterdam, 294 p.

1995. Landforms and structures of the waterlain west end of St. Thomas moraine, SW Ontario, Canada. Geomorphology, 14: 185-196.

Dreimanis, A. and Karrow, P.F., 1972. Glacial history of the Great Lakes - St. Lawrence Region, the classification of the Wisconsin(an) Stage, and its correlatives. Proceedings of the 24th International Geological Congress, Section 12, Montréal, p. 5-15.

Drewry, D.J., 1986. Glacial Geologic Processes. Edward Arnold, London, 276 p.

Elson, J.A., 1957. Origin of washboard moraines. Geological Society of America Bulletin, 70: 1721.

1968. Washboard moraines and other minor moraine types, p. 12131219. In R.W. Fairbridge, ed., Encyclopaedia of Geomorphology. Reinhold, New York, $1257 \mathrm{p}$.

Eyles, N. and Miall, A.D., 1984. Glacial Facies, p. 15-38. In R.G. Walker, ed., Facies Models. Geoscience Canada Reprint Series 1, Second Edition, Toronto, $317 \mathrm{p}$.

Feenstra, B.H., 1981. Quaternary Geology and Industrial Minerals of the Niagara-Welland Area, Southern Ontario. Ontario Geological Survey, Open File Report 5361, Toronto, 260 p.

Fisher, D.A., Reeh, N. and Langley, K., 1985. Objective reconstructions of the Late Wisconsinan Laurentide Ice Sheet and the significance of deformable beds. Géographie physique et Quaternaire, 39: 229-238.

Gartner Lee Associates, 1987. Site Assessment Phase 4B: Geology, Hydrogeology and Geotechnics, Baseline Conditions. Volumes 1 and 2, Toronto, $521 \mathrm{p}$.

Gravenor, G.P., von Brunn, V. and Dreimanis, A., 1984. Nature and classification of waterlain glaciogenic sediments, exemplified by Pleistocene, Late Paleozoic and Late Precambrian deposits. Earth Science Reviews, 20: 105-166.

Gwynne, C.S., 1942. Swell and swale pattern of the Mankato Lobe of the Wisconsin Drift Plain in lowa. Journal of Geology, 50: 200-208.

Henderson, E.P., 1967. Surficial Geology North Shore of the St. Lawrence River, Kingston to Prescott, p. 109-199. In S.E. Jennes, ed., Geology of parts of Eastern Ontario and Western Québec. Guidebook Geological Association of Canada meeting Kingston, Ontario, 54 p.

Hobson, G.D. and Terasmae, J., 1969. Pleistocene geology of the buried St. David's Gorge, Niagara Falls, Ontario: Geophysical and Palynological studies. Geological Survey of Canada, Paper 68-67, Ottawa, 16 p.

Karrow, P.F., 1989. Quaternary geology of the Great Lakes subregion, p. 326350. In R.J. Fulton, ed., Quaternary Geology of Canada and Greenland. Geological Survey of Canada 1 also Geological Society of America, The Geology of North America v. K-1, Chapter 4, Ottawa, 839 p.

Karrow, P.F. and Calkin, P.E., 1985. Quaternary Evolution of the Great Lakes. Geological Association of Canada Special Publication 30, $258 \mathrm{p}$

King, L.H. and Fader, G.B.J., 1986. Wisconsinan glaciation of the Atlantic continental shelf of southeast Canada. Geological Survey of Canada, Bulletin 363, $72 \mathrm{p}$.

King, L.H., Rokoengen, K., Fader, G.B.J. and Gunleiksrud, T., 1991. Tilltongue stratigraphy. Geological Society of America Bulletin, 103: 637-659.

Løken, O.H. and Leahy, E.J., 1964. Small moraines in Southern Ontario. Canadian Geographer, 8: 10-21.

Lundqvist, J., 1989. Rogen (ribbed) moraine - identification and possible origin. Sedimentary Geology, 62: 281-292.

Maarleveld, G.C., 1983. Ice-pushed ridges in the Central Netherlands, p. 393397. In J. Ehlers, ed., Glacial Deposits in North-West Europe. A.A Balkema Publishers, Rotterdam, $470 \mathrm{p}$.

MacKenzie, D., 1990. Quaternary environs of Lakes Erie and Ontario. First joint meeting of the American Quaternary Association and the Canadian Quaternary Association at the University of Waterloo, June 4-6, 1990 , Waterloo. $265 \mathrm{p}$.

Mathews, W.H., 1974. Surface profiles of the Laurentide ice sheet in its marginal areas. Journal of Glaciology, 13: 37-43.
Meer, J.J.M. van der, 1996. Micromorphology, p. 335-356. In J. Menzies, ed. Past Glacial Environments - sediments, forms and techniques. Volume II, Butterworth-Heineman, Oxford, $598 \mathrm{p}$.

Menzies, J., 1986. Inverse-graded units within till in drumlins near Caledonia, southern Ontario. Canadian Journal of Science, 23: 774-786.

1989. Subglacial hydraulic conditions and their possible impact upon subglacial bed formation. Sedimentary Geology, 62: 125-150.

1990a. Sand Intraclasts within a diamicton mélange, southern Niagara Peninsula, Ontario, Canada. Journal of Quaternary Science, 5: 189-206.

1990b. Brecciated diamictons from Mohawk Bay, Southern Ontario, Canada. Sedimentology, 37: 481-493.

1995. The Dynamics of Ice Flow, p. 139-196. In J. Menzies, ed., Modern Glacial Environments - Processes, Dynamics and Sediments. Volume I. Butterworth-Heineman, Oxford, $621 \mathrm{p}$.

1998. Microstructures within subglacial diamictons, p. 153-166. In A. Kostrzewski, ed., Relief and Deposits of Present-day and Pleistocene Glaciation of the Northern Hemishpere - Selected Problems. Adam Michiewicz University Press, Poznan, Geography Series 58, Poznan, $274 \mathrm{p}$.

2000. Micromorphological analyses of microfabrics and microstructures, indicative of deformation processes, in glacial sediments, $p$. 245-257. In A.J. Maltman, B. Hubbard and M.J. Hambrey, eds., Deformation of Glacial Materials. Geological Society Special Publication 176, London, 344 p.

Menzies, J. and Shilts, W.W., 1996. Subglacial Environments, p. 115-136. In J Menzies, ed., Past Glacial Environments - Sediments, Forms and Techniques. Volume II. Butterworth-Heineman, Oxford, 598 p.

Menzies, J. and Taylor, E.M. 1999. Urban Geology of St Catharines-Niagara Falls, Region Niagara, p. 287-321. In P.F. Karrow and O.L. White, eds. Urban Geology of Canadian Cities. Geological Association of Canada Special Paper 42, St. John's, 500 p.

Owen, E.B., 1969. Stratigraphy and engineering description of the soils exposed on a section of the Welland Canal By-Pass Project (Contract 743) Ontario, Canada. Geological Survey of Canada, Paper 69-31, Ottawa, $22 \mathrm{p}$.

1972. Geology and engineering description of the soils in the WellandPort Colborne area, Ontario. Geological Survey of Canada, Paper 71-49, Ottawa, $7 \mathrm{p}$.

Powell, R.D., 1981. A model for sedimentation by tidewater glaciers. Annals of Glaciology, 2: 129-134

1988. Processes and facies of temperate and subpolar glaciers with tidewater fronts. Short Course Notes, Geological Society of America, Denver, $114 \mathrm{p}$.

1990. Glacimarine processes at grounding-line fans and their growth to ice-contact deltas. In J.A. Dowdeswell and J.D. Scourse, eds. Glaciomarine Environments: Processes and Sediments. Geological Society of London, Special Publication 53, $423 p$.

Punkari, M., 1980. The ice lobes of the Scandinavian Ice Sheet during the deglaciation in Finland. Boreas, 9: 307-310.

Sættem, J., 1990. Glaciotectonic forms and structures on the Norwegian continental shelf: Observations, processes and implications. Norsk Geologisk Tidsskrift, 70: 81-94.

Sharp, M.J., 1985. "Crevasse-fill" ridges - a landform type characteristic of surging glaciers? Geografiska Annaler, 67A: 213-220.

Sharpe, D.R. and Barnett, P.J., 1985. Significance of sedimentological studies on the Wisconsinan stratigraphy of southern Ontario. Géographie physique et Quaternaire, 39: 255-273.

Solheim, A., Russwurm, L., Elverhøi, A. and Nyland Berg, M., 1990. Glacial geomorphic features in the northern Barents Sea: Direct evidence for grounded ice and implications for the pattern of deglaciation and late glacial sedimentation, p. 253-268. In J.A. Dowdeswell and J.D. Scourse, eds., Glaciomarine Environments: Processes and Sediments. Geological Society of London, Special Publication 53, $423 \mathrm{p}$.

Talbot, C.J. and Von Brunn, V., 1987. Intrusive and extrusive (micro)melange couplets as distal effects of tidal pumping by a marine ice sheet. Geological Magazine, 124: 513-525. 
Thomas, G.S.P. and Connell, R.J., 1985. Iceberg drop, dump and grounding structures from Pleistocene glacio-lacustrine sediments, Scotland. Journal of Sedimentary Petrology, 55: 243-249.

Van der Wateren, D.F.M., 1995. Processes of Glaciotectonism, p. 309-335. In J. Menzies, ed., Modern Glacial Environments - Processes, Dynamics and Sediments. Volume I, Butterworth-Heineman, Oxford, $621 \mathrm{p}$

Vincent, J.-S. and Hardy, L., 1979. The evolution of glacial lakes Barlow and Ojibway, Québec and Ontario. Geological Survey of Canada, Bulletin 316, Ottawa, $18 \mathrm{p}$
Woodworth-Lynas, C.M.T., 1996. Ice scour as an indicator of glaciolacustrine environments, p. 161-178. In J. Menzies, ed., Past Glacial Environments: Sediments, Forms and Techniques. Volume II, Butterworth-Heineman, Oxford, $598 \mathrm{p}$.

Zilliacus, H., 1989. Genesis of De Geer Moraines in Finland. Sedimentary Geology, 62: 309-317. 